\title{
Education, State and Agency in Dystopian Children's Texts
}

\author{
Margaret Aitken, Clare Bradford and Geraldine Massey
}

Formulations of utopian and dystopian societies have always engaged with the politics of state power and government, since the better worlds envisaged in utopian thinking commonly rely on the interplay of individual, communitarian and political interests and concerns. Tom Moylan remarks of science fiction during the 1980s that initially it 'changes the central power structure from the state to the corporation' (2003, pp.136-7), but that toward the end of the twentieth century 'the later critical dystopias move to a fresh consideration of the role of the state, eventually examining its relationship to the oppositional movements within the dystopian societies' (2003, p.137). Such oppositional movements in late twentieth-century fiction respond to real-world unease over the directions of neo-liberal national politics and their propensity both for instituting regimes of surveillance and control, and for developing unhealthy partnerships with corporations. Thus, the fin de siècle turn which Moylan observes, involving a re-consideration of the role of the state, critiques corporate power at the same time that it interrogates neo-liberal government.

In his collection of essays Acts of Resistance (1998), Pierre Bourdieu argues that 'The national states are undermined from outside by ... financial forces, and they are undermined from inside by those who act as the accomplices of these financial forces, in other words, the financiers, bankers and finance ministry officials' (1998, pp.40-41). While hierarchies of power are based on access or lack of access to capital, the discourses which are deployed to normalise disparities between individuals and groups in modern nation states rely on both ethical and intellectual justifications. Ethical justifications for the existence of deep divisions between rich and poor, employed and unemployed, call on traditional distinctions between the deserving and the undeserving poor; and intellectual justifications deploy discourses of intelligence and capability: 'The poor are not just immoral, alcoholic and degenerate, they are stupid, they lack intelligence' (1998, p.43). Bourdieu views education, and specifically the education of children and young people, as a site of struggle over the future of societies, since educational systems "not only [shape] social destinies but also the image [people] have of their destiny' (1998, p.43).
Dystopian and utopian discourses as they manifest in children's texts are inflected by questions of agency, often played out through narratives in which protagonists forge identities as members of communities and citizens of nations. In line with Bourdieu's argument that education shapes not merely what children know but how they regard themselves and the possibilities open to them, educational institutions and processes figure prominently in two endof-century texts: Rachel Anderson's The Scavenger's Tale (1998), and Nina Bawden's Off the Road (1998). Both these texts are set in Britain, in twenty-first century postdisaster societies where powerful groups have established authoritarian regimes reliant on strategies of inclusion and exclusion. The protagonists of the two novels, Bedford in The Scavenger's Tale and Tom in Off the Road, belong, respectively, to excluded and included groups within highly-stratified sociopolitical formations.

Bedford, so named because his surrogate mother, Ma Peddle, found him as an abandoned infant in a back lane called Bedford Court, is classified as a Low-Caste but High Intelligence Quotient citizen, and lives in London City Sector One together with his family of Dysfuncs (short for Dysfunctionals, those with physical or intellectual disabilities). Tom, in Off the Road, is the child of parents who live in Urb Seven, a large urban conglomerate in a highly mechanised and controlled society where 'Everyone had all they wanted or needed, which were exactly the same things as everyone else' (Bawden 1998, pp.46-7). In the Urbs there is a strict one-child rule and children are pampered and privileged over adults. Outside the Urbs is the Wild, where (so Tom has been taught) live dangerous, lawless and deformed creatures who are prevented from breaking into the Urbs by walls which are constantly patrolled according to the orders of the Protectors, members of the ruling body which governs the society constituted by the Urbs. While Bedford and Tom are poles apart in relation to the sociocultural settings into which they have been born, they are alike in that they embark on journeys which are emblematic of shifts in comprehension and insight and which require a transformation of world view.

The role of institutional education is similar in the two narratives: to form what Michel Foucault characterises as 'docile bodies'(1979, pp.135-69), individuals so thoroughly 
subjected to state ideologies that they are powerless against social engineering, control and manipulation. In The Scavenger's Tale, Bedford attends a school whose mission statement, written on the school walls, is: 'A place for everybody. Everybody in their rightful place. The child's place is in his school' (Anderson 1998, p.41). Lessons on 'Civic Responsibility, Politics, and World Order' seek to prepare the children for the roles which they will be allocated as adults, and strategies of recitation and rote learning are employed to deaden creativity and to shape subjects convinced of the Panglossian maxim that 'Sector One in every way, gets better and better day by day' (Anderson 1998, p.38). In a somewhat similar way, Tom, in Off the Road, is taught that humans, 'rolling off the assembly line, [are] identical living and breathing machines' (Bawden 1998, p.14), and that the ideal citizen is one intent on realising the aims and purposes determined by the state for each of its inhabitants. The educational systems of these societies are intent not on teaching knowledge and skills but on damping down students' capacity to think independently and to be critical of state ideologies. Both novels propose that real education involves an unlearning of the lessons inculcated by state educational institutions, and reliance upon other, non-institutional resources and systems of knowledge.

In The Scavenger's Tale, an evil alliance of state and economic forces centres on a market for human body parts. Since the 'Conflagrations' (a euphemism for wars) which ravaged Sector One, its agricultural and industrial production has collapsed. The Sector's most valuable assets are its citizens, or more accurately its impoverished and powerless inhabitants, whose bodies can be harvested for parts for the wealthy and unwell citizens of other Sectors and nations. As the Sector's rulers become greedier or more desperate for capital, they hasten the process of culling in order to increase the number of citizens whose bodies are available for organ transplants. In the Newspeak of the Sector, the school which Bedford attends is affected by a 'Temporary Change of Usage' during which it becomes the 'Infant and Youth Special Re-Assessment Centre' (Anderson 1998, p.48). Children identified as 'special'(the Abnormals and Dysfuncs) are implanted with microchips in order that their body parts will be available for collection as the need arises - that is, when a rich, ill, foreign tourist requires corneas, kidneys, hearts, lungs, livers. Thus re-assessed, microchipped children are collected by the Community Health and Welfare Monitors (CHAWMs) in their white Carecars and taken to the organ transplant centre where body parts are harvested.

From his position in the lowest reaches of the sociocultural system, Bedford understands very little about the motivations and policies of those in power in London City Sector One. Through a combination of state education and state-administered deterrents, he has been thoroughly conditioned to adhere to the rules of appropriate conduct, such as 'Community Living Regulation 128A' which says that 'LC [lower caste] citizens are prohibited from endeavouring to seek fraternity with, or in any other way causing irritation to, esteemed visitors' (Anderson 1998, p.47). The agents of government, such as the Monitors, present an impenetrable front to Low-Caste citizens: they are clean, blue-eyed, fresh-smelling and smiling figures who speak only the formulaic discourses of officialdom. In contrast to the sterility and the controlling discourses of the state, the 'Ab Mix' (mixture of Abnormals) household of Ma Peddle affords an alternative style and form of education. Ma Peddle, herself a 'Dysfunc' because she is almost blind, has created an environment represented by the narrative as both admirable and also as doomed. To the group of abandoned 'Low-Caste' children whom she has rescued - all, apart from Bedford, with profound disabilities - she offers unconditional love, the scanty resources available to her, and stories.

During the household ritual known as 'Tale-Times', Ma Peddle tells the stories she recalls from her own childhood in the 'Pre Post War times'. The authorities have no capacity to control the private dissemination of these narratives, which Bedford describes as follows:

Some of [Ma Peddle's stories] are brilliant, about kings and lions, shooting stars, famines and splendid celebrations during years of plenty. Last week she told one about a man who was so afraid of a rumoured global flood that he built himself a wooden boat and loaded it with all the animals and plants he could find.

(Anderson 1998, p.23) 
The combination of folktales, mythology and biblical narratives signalled in Bedford's account of the Tale-Times constitutes an education capable of shaping Bedford's view of the world. Ma Peddle's actions and the principles she espouses offer another form of instruction: 'Our Ma Peddle reckoned that Dysfunctionals and Abs had the same basic right to education, food, justice, as every other citizen. Some hope' (Anderson 1998, p.3). However, as Bedford's 'Some hope' indicates, readers are positioned to read Ma Peddle's system of beliefs as hopelessly optimistic; and when, one by one, the members of the household fall prey to the CHAWMs for the purposes of organ transplants, the fragile utopia of the Peddle household collapses.

Bourdieu's reading of what he describes as 'conservative revolutions' is that rather than evoking the values of simple, pre-industrial society, they appeal to 'progress, reason and science...to write off progressive thought and action as archaic' (1998, p.35). Ma Peddle's conviction that her family of Dysfuncs (who include Dee, a girl with Downs syndrome, Netta, a three-year-old with cerebral palsy, and Rah, a microcephalic boy) are sentient humans capable of learning and loving is, in Bourdieu's terms, progressive and hence written off as archaic in the face of the eugenicist and mercantile values of the society of The Scavenger's Tale. Nevertheless, later in the novel, when he is thrown on his own resources in the harsh world of Sector One, Bedford rehearses Ma Peddle's sayings and stories, drawing on them as a guide to right thinking and moral behaviour, and in this way the narrative demonstrates his internalisation of the principles and ideas which she has taught him.

IfMa Peddle is unable to protect her charges - Rah and Netta are taken away to be plundered for body parts - Bedford is also unable to protect his favourite sister, Dee. More than this, he consigns her to certain death in an episode where he and Dee are stalked by two Monitors:

The CHAWMS were so cool ....

'No, not me, you fools. I'm not a Dysfunc. Take her. She's the dappy Mongol.'

'We need the both of you, dear. A little DJLDS [Doctor John Langdon Down Syndrome] child and a size twelve liver. Such an honour to do this for one's community. Your name glorified for ever.'

\section{I pushed Dee towards them. May her name be glorified forever.}

(Anderson 1998, p.79)

The language of this interchange, and the starkness of Bedford's choice, make this the most shocking moment of the novel, particularly as the narrative has previously foregrounded the mutual affection which Dee and Bedford enjoy, and his sense of responsibility for her welfare. The use of the terms 'Dysfunc' and 'dappy Mongol' as signifiers for 'Dee' enforce the idea that 'Dysfunc', 'dappy Mongol' and 'little DJLDS' are equally ugly manifestations of the principle that because of her extra chromosome Dee is rendered abnormal and hence expendable. Enunciated by Bedford, the descriptor 'dappy Mongol' performs a ventriloquising function, modulating into his act of pushing Dee toward the Monitors in order that he himself can escape. Readers are likely to hesitate over the meaning of Bedford's 'May her name be glorified forever', which might constitute either a cynical acquiescence to the new order, or a desperate prayer. The ambiguity of this sentence, together with Bedford's action, disrupts the narrative's strategy of positioning readers to align themselves with Bedford and achieves a distancing effect, inviting reflection on the ethical implications of the episode and on the social and political forces which intersect in the struggle between Bedford and the Monitors.

Unable to return to Ma Peddle's home, Bedford seeks refuge in an old church, 'historic Heritage Centre, number 5'(Anderson 1998, p.88) where he is discovered by a priest, Father Gregory, who rescues the marginalised children of the Sectors and sends them to 'Mother Church', a monastery-like institution separated by the Thames from Sector One and frequented by tourists and pilgrims. In Father Gregory's church, Bedford comes across his former school-friend Callam, who belonged to a High-Caste family but has been classified as an Abnormal because of a physical abnormality: he has six toes on one foot. Finding that his father intends to sell him for a large amount of money (because healthy high-caste children are in demand for organ transplants), he has run away, found refuge with Father Gregory and become a devout convert. 
Callam and Bedford represent opposing perspectives of the capacity of organised religion to provide meanings and structures for human life. In the penultimate chapter of the novel, the boys reach Mother Church together with the Dysfuncs who have joined them on their journey. However, the Tribunal of Mother Church refuses to offer the children refuge because of 'the menace they are to visiting foreigners, the threat they pose to hygiene, the air of degeneracy and misery they create' (Anderson 1998, p.125), and instead they are licensed as official beggars and set to gather money intended to fund the building of a 'mental disability asylum, ...the most blessed manifestation of true civilization any caring community can present' (Anderson 1998 p.127). Whereas Callam puts his faith in the good intentions of Mother Church, Bedford remembers Ma Peddle and his former family, and resolves to search for human companionship rather than to merely 'exchange one kind of Low-Caste misery for another' (Anderson 1998, p.129).

Despite the controls and regulations which have circumscribed his life, despite the social engineering of City Sector One, despite his lowly caste, Bedford has learned both from Ma Peddle's stories and from the chance encounters of his journey that there is a world beyond the dystopian world of City Sector One. A crate marked 'Pineapples, Sierra Leone' on the container ship which transports him to Mother Church signifies the possibility that places of hope and plenty exist, and that he may one day discover them. At the end of the novel he escapes from Mother Church, carrying a gold chalice scavenged for him by the gatekeeper, who gives it to Bedford in memory of his own son, who was culled as a Dysfunc. Bedford's memory of the smell of pineapples, his experience of belonging to a family, and his empathy with Dysfuncs enable him to imagine a better world, and when he leaves Mother Church together with a blind boy whom he has befriended, he considers alternative futures:

I don't know where we're going. Will we find a way back across the river, head north ...? Or will we walk over to the west, to find one of the New Age settlements that's willing to take us in?
Or perhaps misfits like us can't ever belong anywhere and have to keep roaming forever, till the end of our days.

(Anderson 1998, p.131)

That Bedford refers to himself as a misfit, not 'ever belonging anywhere' and 'roaming forever' may indicate that his identity will always be fluid, always trapped in a cyclical pattern of travel. Or his sense that he is a social being, 'we' rather than simply 'I', may signal his potential to find a place to belong, a territory without social domination. The glimmers of hope offered by the New Age settlements are literally and metaphorically on the horizon, in the future; Bedford's most significant advance is that he has seen state power for what it is and recognises that he is free to oppose its hold on him.

Whereas Bedford hopes for and imagines the possibility of a better place, Off the Road constructs two societies which appear to represent dystopian and utopian possibilities. The narrative of this novel is structured by an opposition between the Urbs, where Tom lives with his parents and grandfather, and the world on the other side of the Wall. In the Urbs, society is highly mechanised and tightly controlled by the Protectors and the Guardians, remote figures who, like the rulers of the Sectors in The Scavenger's Tale, exercise their power through surveillance, regulation and control of language. In both novels, the state's practices of killing its unwanted citizens are concealed by euphemisms which maintain the fiction of a caring and considerate bureaucracy. Like the society of Lois Lowry's The Giver, the world of the Urbs is more an anti-utopia than a dystopia, since it offers the appearance of a utopian world while undermining the utopian project by denying its citizens freedom. ${ }^{1}$ The inhabitants of the Urbs live by regulation: families are allowed one child; adults compulsorily retire at sixty; and when they reach sixty five these 'Oldies' are regarded as brain-dead and expendable and must report to the Memory Theme Park where they are 'gently and permanently cared for' (Bawden 1998, p.27). Most of the indoctrinated residents of the Urbs, like those of the community in The Giver, believe themselves to live in an ideal society. 
When Tom and his parents, Penelope and William, are taking Gandy, Penny's father, to the Memory Theme Park, Gandy makes the excuse of visiting a lavatory to escape through the Wall. Tom follows him, believing his grandfather needs rescuing, and once he is on the other side is unable to return because of the vigilance of the Rangers who guard the Wall on the other side. Like Bedford in The Scavenger's Tale, Tom learns to critique the discourses of the society in which he has grown up. However, as we will argue, the liberatory possibilities of his encounter with the Outside world are limited by the social and political conservatism of this culture, which comprises former citizens of the Urbs, who either chose to leave or were forced to leave when the Wall was erected, including his grandfather's brother Jack, and the large family he has gathered around him during his years Outside.

The world over the Wall is a largely pre-industrial agricultural society which reflects the political and social theories of orthodox communitarianism; Adrian Little's description closely matches the world Tom encounters when he follows his grandfather:

The traditional community espoused by orthodox
communitarians focuses on methods of reasserting
the primacyof the family (often defined in somewhat
conservative fashion) as the most important unit
within society .... Moreover the traditional family
model is frequently combined with the protestant
work ethic (especially for men) in a strategy to
counteract the changes to family life and patterns
of work in contemporary Western society.
(Little 2002, p.59)

In the Outside world, family is the basis of community and of society, whereas Tom's life up to this point has been structured by state regulations which determine the whole of human life. In the one-child families of the Urb, only 'mother', 'father' and 'grandparents' are acceptable terms; 'brother and sister were disgusting: among the nastiest, most insulting names you could call anyone' (Bawden 1998, p. 18). When Tom is introduced to his great-uncle Jack's family, he must learn a new language pertaining to the network of family, incorporating brothers, sisters, cousins, uncles and aunts. Signifiers such as 'brother' and 'sister' mean differently in this setting, being associated with positive associations and notions about the obligations of family members to support one another.

In line with Little's description of the traditional community, the family structure in the Outside is patriarchal and heavily gendered: housework and child-care are performed solely by women and girls while men carry out farm-work. Tom must learn to observe regimes of politeness and interpersonal exchanges quite different from those to which he is accustomed. That concepts such as 'politeness' are based on power relations is clear when Tom is reprimanded by his great-uncle for speaking when he has not been spoken to: 'I think you'll find the pecking order is a bit different here from home. So mind your manners, speaking to older folk. Won't hurt you, and you'll fit in a bit easier' (Bawden 1998, p.66). Tom finds that most of the adults 'sort of bark at you here. And expect you to jump when they say so'(Bawden 1998,p.94); and his initial reluctance to comply with the practices of the Outside world is read as ignorance by his new family.

By positioning readers to align themselves with Tom, the narrative constructs as admirable a society which offers him new freedoms and pleasures. Whereas in the Urbs he has been taught that trees are dangerous and hostile to children, in the Outside he learns to climb trees and pick fruit; the factory-produced products to which he is accustomed are replaced by 'natural' foods, such as freerange eggs and fresh vegetables from the farm garden; he enjoys the companionship of his cousin Lizzie; and becomes the favourite of Joshua, one of the toddlers of his extended family. He learns, too, that in the Outside citizens elect their leaders, an idea which strikes him as dangerous because, he thinks, they might choose the wrong person.

In this seemingly utopian world there is, however, an underclass, comprising 'Dropouts' who live in the Wild beyond the farms. Tom's Aunt Polly explains that when the Wall was erected, those who left the cities were of two kinds: those, like his great-uncle Jack Jacobs, who desired independence; and a category of unwanted, comprising criminals and the sick. Some of the Dropouts are criminals; others, like Jack Jacobs' youngest son, are 'trolly-lolly boys, lazybones who thought it would be nice to give a hand with the harvest occasionally, but were better at getting their 
feet under the table and drinking and singing than doing a proper day's work' (Bawden 1998, p.102).

Whereas state intervention affects almost every aspect of the lives of citizens in the world of the Urbs, regimes of power in the Outside world are less evident. Nevertheless, systems of surveillance and control are in place to identify any departures from what is considered normal. The advent of Tom and his grandfather, for instance, comes to the attention of the Rangers, who police the Wall and track down unauthorised visitors, or Illegals. While Tom's grandfather is entitled to remain because of his age, Tom is threatened with expulsion and his great-uncle reprimanded for his attempt to pass him off as his own grandson. The extent of state control is signalled in an exchange between the Rangers and Jack Jacobs, when one of the Rangers outlines the dangers of infiltration across the Wall:

'Let me explain, Mr.Jacobs. Think what would happen if we let in too many! They would swamp us. They would have to be fed. They would want jobs and land. Or they might join up with our Dropouts and become even more of a nuisance.' He lowered his voice as if what he was about to say was the worst thing of all. 'If they haven 't already been sterilized, they will start to breed.'

(Bawden 1998, pp.181-2)

The language of this warning is strikingly reminiscent of the discursive strategies of contemporary nations as they condition citizens to fear the consequences of 'invasion' by refugees - that 'they' will take 'our' food, work and land, that 'they' are likely to be criminals, that 'they' will breed and outnumber us. Nevertheless, this passage cannot be read simply as a criticism of how these discourses are deployed in contemporary societies, since Tom's great-uncle persuades the Rangers to allow Tom to stay, demonstrating that some refugees (in Tom's case, because of his family connections) are more acceptable to the society of the Outside than others. Simon Watkins, the carrier and postman who offers Tom and his grandfather a ride soon after they enter the Outside, has informed the Rangers of his suspicions regarding the new arrivals, an action which the Rangers applaud as that of a 'responsible citizen'(Bawden 1998,p.181). Again, because the Outside is represented in such positive terms, any criticism which might be laid against Simon Watkins for his role as informer is undercut by the notion that the citizens of the Outside are justified in protecting their territory.

During his interview with the Rangers, Tom is astonished to discover that the Outsiders believe that their society is on the 'right' side of the Wall. When Tom protests that the Wall exists to keep the citizens of the Urbs safe rather than to lock them out, one of the Rangers tells him, 'That's what you're meant to think, boy. For your own good. What would be the point in knowing that you're on the wrong side of the fence?' (Bawden 1998, p.182). The 'natural' world of the Outside is overtly presented not only as the ideal world but also as the 'real' world; Tom's grandfather remarks that his Ordnance map of the area, illegal since the Millenium, 'must be just about the last map of the real world in existence' (Bawden 1998, p.26).

Although Off the Road does not foreground the alliance of state and business in anything approaching the manner of The Scavenger's Tale, the contrast between the Urbs and the Outside is mapped onto a distinction between late-capitalist and pre-industrial cultures. Tom confides in his great-uncle that he is destined to become a 'refuse disposal engineer' (Bawden 1998, p.114), the occupation determined for him by a computer programme which calculates the needs of the state, the numbers of workers required, and the fit between an individual's abilities and the requirements of various occupations. When Jack Jacobs inquires as to the nature of farming in the Urbs, Tom's reply underscores the transformation of farming into business in late modernity:

'I think farming must be quite dull. You have to commute out of your Urb every morning. And you either have a barley farm, or a wheat farm, or you just grow potatoes. Or you have an egg factory. They're all factories, really. Nothing to do except look after the machinery.

(Bawden 1998, pp.114-5)

In response, Jack Jacobs shows Tom the farm's mare with her appealing twin foals, and teaches him to gather the scythed wheat into sheaves. Without machinery of any kind, farming in the Outside requires hard physical work, and after Tom has worked for half a day he is rewarded 
by the praise of his Uncle Ted: 'You've not done bad for an Insider!' (Bawden 1998, p.118). The sensory detail of the novel's description of rich green grass, Tom's aching muscles and sweat, and the simple, wholesome food he is given at lunch, constructs farming in terms of honest toil and closeness to nature, so offering a romanticised, nostalgic picture of pre-industrial agriculture.

Tom's re-education on the Outside is effected through direct instruction by adults, training in farming skills, and through incidents which test his capacity for endurance and determination. Book-learning is, however, a distinctly female preoccupation: Tom's Aunt Polly conducts a school in the farmhouse, in a room full of wooden desks, blackboards, and books. Tom has encountered instructional manuals in the world of the Urbs, but works of fiction and poetry are forbidden there, since, in the words of the Chief Tutor, they 'put ideas in people's heads' (Bawden 1998, p.177). The Outside world, too, values conformity and action over intellectual pursuits. On his first day at the farm, Tom's great-uncle sets him to work in the fields rather than sending him to the schoolroom; in the gendered setting of the farm, to be a proper boy is to gravitate to the outside world rather than to the domestic domain where the school is located.

Two female characters, Tom's cousin Lizzie, and his greataunt Tess, offer some resistance to the patriarchal system in which they are trapped. The intelligent and independent Lizzie, obliged to care for toddlers and babies and forbidden from speaking her mind as a doubly-marginalised girl child, decides at the end of the narrative to accompany Tom as he returns to the Urbs. She is motivated by a desire for adventure, but also for a regime which, she imagines, will be more to her liking. She says to Tom,

\begin{abstract}
'It [the Urbs] sounds my kind of place. Eggs already in boxes and no babies snivelling. And kids on top. Having the first and last word and all the in-between words. I'm not saying I'll stay all that long, mind.'
\end{abstract}

(Bawden 1998, p.187)

Here, Bawden's gesture toward principles of gender equality is undercut by Lizzie's enunciation of her reasons for leaving the Outside: factory-produced eggs, relief from child-minding, a place where she will be 'on top' of hierarchies of importance. Tess's reasons for regretting that she moved to the Outside as a young woman include her nostalgia for bourgeois life: 'Oh, I do miss it,' she said. '...I used to watch Neighours and Baywatch. And videos. Oh Thomas Jacobs! I'd give my soul for a video' (Bawden 1998, p.90). Dissatisfied with a life without television, dishwashers, cars, telephones and Mars Bars, Tess has taken to her bed as an invalid; but the more significant reason for her unhappiness is that her son Charley lives with the Dropouts, having defied his father's autocratic rule. The narrative is inconclusive as to whether Charley will return to his family, and Tess decides, as she says, to 'make the best of a bad job' (Bawden 1998, p.144) and to return to family life. Since the patriarchal order is normalised as fundamental to a world where simplicity of life, hard physical work and family unity afford happiness, Lizzie's and Tess's discontent is folded into traditional views of the feminine as fickle, pleasure-loving and shallow.

Both The Scavenger's Tale and Off the Road feature indeterminate endings; but only The Scavenger's Tale fits within the critical dystopias described by Baccolini and Moylan, which 'allow both readers and protagonists to hope by resisting closure' (2003, p.7). When Tom decides to return to the Urbs so as to carry the message of the better world offered by the Outside, he explains his reason to his grandfather:

\section{'It's just, they should know. Someone should tell them. Not just my mother and father. Everyone ought to know. For all sorts of reasons. Peopleyour age! And people like me who would like a brother or sister! But it's mostly the lies we've been told. They are all lies, aren't they?'}

(Bawden 1998, p.184)

In discussing the dystopian shift toward representations of an unhealthy alliance between state and economic forces, Moylan notes that 'the success of the attacks on the welfare and regulatory state by the ideologues of the "free market" has legitimated a general suspicion of the state as a mechanism for delivering social justice and democratic and ecological well being' (2003, p.140). The Scavenger's Tale speaks to this suspicion in its representation of a state preying on the bodies of its citizens. Like Chaucer's 
pilgrims, Bedford tells a story framed within a journey. In the novel's final chapter, past tense modulates into present, as Bedford embarks on the next phase of his pilgrimage. The story he has told descries his seizure of agency, and his transformation from cynical resignation to a sense of possible futures opens up the hope for a better world. In Off the Road, Tom's return to the Urbs does not represent such a pilgrimage. While Bawden's novel clearly incorporates a suspicion of state control, the world of the Outside, with its romanticised and idealised representation of preindustrial society, embodies another version of totalitarian rule where a conservative patriarchal past is reinstated. By implying the impossibility of utopian imaginings based on autonomy and equality, Bawden in effect constructs another anti-utopia. Tom's agency within this anti-utopian culture is both partial and privileged: he must (unlike Charley) acquiesce to a totalising order; and as a boy he is destined to wield power within this order.

This essay is an outcome of a project funded by the Australian Research Council.

\section{NOTES}

1. Fredric Jameson describes anti-utopia as 'the expression of the fiercely anti-utopian and anti-revolutionary ideology for which utopias inevitably lead to repression and dictatorship, to conformity and boredom' (2004, p.54), as distinct from critical utopias, which critique negative aspects of the society in which they are produced.

\section{REFERENCES}

Anderson, Rachel (1998) The Scavenger's Tale. Oxford, Oxford University Press.

Baccolini, Raffaella, and Moylan, Tom (2003) 'Introduction: Dystopia and histories', in R. Baccolini and T. Moylan (eds) Dark Horizons: Science Fiction and the Dystopian Imagination. New York and London, Routledge, pp.1-12.

Bawden, Nina (1998) Off the Road. New York, Clarion Books.

Bourdieu, Pierre (1998) Acts of Resistance: Against the Tyranny of the Market, trans. R. Nice. New York, The New Press.
Foucault, Michel (1979) Discipline and Punish: The Birth of the Prison, trans. A. Sheridan. New York, Random House.

Jameson, Fredric (2004) 'The politics of utopia', New Left Review 25, Jan-Feb: 35-54.

Little, Adrian (2002) The Politics of Community: Theory and Practice. Edinburgh, Edinburgh University Press.

Moylan, Tom (2003) "“The moment is here...and it's important": State, agency, and dystopia in Kim Stanley Robinson's Antarctica and Ursula K. Le Guin's. The Telling', in R. Baccolini and T. Moylan (eds) Dark Horizons: Science Fiction and the Dystopian Imagination. New York and London, Routledge, pp.135-153.

\section{BIOGRAPHICAL NOTES}

Margaret Aitken has worked as a children's librarian, and as state consultant for children's services in public libraries with the Library Council of Victoria. She completed her M.Ed with Deakin University and has lectured in children's literature at various tertiary institutions.

Clare Bradford is Professor of Literary Studies at Deakin University in Melbourne, where she teaches literary studies and children's literature and supervises students undertaking $\mathrm{MA}$ and $\mathrm{PhD}$ programmes. Her most recent book is Reading Race: Aboriginality in Australian Children's Literature (Melbourne University Press, 2001), which won the Children's Literature Association Book Award and the IRSCL Award. She is the editor of the journal Papers: Explorations into Children's Literature and her forthcoming book, Unsettling Narratives: Postcolonial Readings of Children's Literature, is a comparative study of settler society literatures for children.

Geraldine Massey has worked in the School of Cultural and Language Studies in Education, QUT, as a tutor in Children's Literature, and Teaching Adolescent Literature. She has also worked as a Research Assistant on the ARC funded project, Transformative Utopianism: Contemporary Children's Literature Responding to Changing World 
Orders from Glasnost to 11 September, 2001. Geraldine is about to embark on a PhD which will explore Australian children's literature and environmental ethics. 